\title{
Definisjon og klassifikasjon av revmatiske sykdommer
}

\author{
Jan Tore Gran \\ Revmatologisk avdeling, Rikshospitalet-Radiumhospitalet
}

I følge Verdens Helseorganisasjon (WHO) dekker fagfeltet revmatologi diagnostikk og behandling av smertefulle tilstander i bevegapparatet. Slike tilstander deles inn i fire hovedgrupper (Tabell 1).

Gruppe I omfatter de inflammatoriske revmatiske sykdommer. Denne gruppen kan det være hensiktsmessig å igjen dele inn i to undergrupper, de inflammatoriske leddsykdommer og de systemiske bindevevssykdommer. Inndelingen innebærer imidlertid ikke noe skarpt skille mellom disse to undergruppene da de begge ofte medfører betennelseaktige forandringer både i ledd og i ekstraartikulære organer. For den diagnostiserende lege kan imidlertid subgrupperingen være nyttig da gruppene oppviser tydelige forskjeller i prognose, organaffeksjon og biomarkører for diagnose.

Inflammatoriske leddsykdommer omfatter blant annet sykdommer som revmatoid artritt, krystallartritter, Behkterevs sykdom, reaktive artritter, og psoriasisartritt. De tre siste klassifiseres i en felles gruppe som kalles seronegative spondyloartropatier. Disse sykdommene har som regel non-destruktiv artritt, affeksjon av iliosakralledd og kolumna, mangler autoantistoffer og er assosiert med den genetiske markøren HLA-B27. De skiller seg derfor fra revmatoid artritt hvis pasienter ofte har destruktiv perifer artritt, serum revmatoide faktorer og anti CCP antistoffer og er assosiert med den genetiske markøren HLA-DR4.

Systemiske bindevevssykdommer kjennetegnes ved multiorganaffeksjon, sykdomsassosierte autoantistoffer, og patologiske lesjoner som vaskulitt og granulomatøs betennelse. Ikke alle sykdommer i denne undergruppen av inflammatoriske revmatiske sykdommer har alle disse kjennetegnene. Multiorganaffeksjon sees sjelden ved vaskulittsykdommer som Takayasu arteritt og arteritis temporalis med mindre det angrepne kar medfører ischemi i det organet karet skal forsyne. Ved disse to sykdommene kan det heller ikke påvises autoantistoffer. Vaskulitt sees heller ikke ved alle systemiske bindevevssykdommer, for eksempel er slike lesjoner en sjeldenhet ved primært Sjøgrens syndrom og systemisk sklerose. Noen velger derfor å inndele systemiske bindevevssykdommer i vaskulittsykdommer og non-vaskulittiske systemsykdommer. Vaskulittsykdommene kan klassifiseres i henhold til størrelsen på de kar som oftest affiseres.

Gruppe II omfatter de degenerative revmatiske sykdommer. En svært viktig diagnosegruppe her er artrose som kan affisere de fleste aksiale og perifere ledd. Om artrose kan sees på som en ren degenerativ brusksykdom, eller om det også her foreligger en initial inflammasjon er fremdeles uklart. Artrose er i en hel- seøkonomisk sammenheng svært viktig da tilstanden er hyppig og rammer den eldre befolkning som jo i årene fremover øker. Å betrakte denne diagnosegruppen som "belastningssykdommer" er etter forfatterens mening noe misvisende da artrose også rammer perifere ledd som ikke utsettes for særlig fysisk belastning. Videre sees artrose forholdsvis sjelden i ankelledd hvor den fysiske belastning er betydelig.

Tabell 1. Inndeling av revmatiske sykdommer (forenklet).

I. Inflammatoriske revmatiske sykdommer

a. Inflammatoriske leddsykdommer

a1. Revmatoid artritt og beslektede sykdommer

a2. Seronegative spondyloartropatier

a3. Andre inflammatoriske leddsykdommer

b. Systemiske bindevevssykdommer

b1. Vaskulittsykdommer

- SLE og beslektede sykdommer

- ANCA assosierte vaskulittsykdommer

- Kjempecellearteritter

- Andre

b2. Non-vaskulittiske systemiske bindevevssykdommer

II. Degenerative revmatiske sykdommer

III. Bløtdelsrevmatisme

IV. Revmatiske manifestasjoner ved primært ikkerevmatiske sykdommer

Gruppe III er helseøkonomisk sett den viktigste gruppen av de revmatiske sykdommer. I denne gruppen klassifiseres diagnosegrupper som "low back pain", myalgier og fibromyalgi. Sett i forhold til den betydning disse tilstandene har for folkehelsen og for helseøkonomien må man kunne hevde at den er blitt stemoderlig behandlet av vårt helsevesen. Det satses for lite på forskning og omsorgen er spredd på flere ulike medisinske spesialiteter uten noen klar grenseoppgang mellom de forskjellige. Lokale forhold er avgjørende for hvem som tar hånd om disse pasientene. Da kurativ medisinsk behandling ofte mangler vil pasientene i denne gruppen ofte bli tilbudt behandlinger som verken er vitenskapelig begrunnet eller utført av personer med faglig kompetanse. En mer organisert forskningsvirksomhet både i grunnforskning og i epidemiologisk forskning er høyst påkrevet og kan gi be- 
tydelige gevinster. For eksempel regnet man for flere år siden ut at dersom man i gjennomsnitt sparte 1 sykedag for hver pasient med "low back pain" ville dette i USA gi en samlet utgiftsreduksjon på 1 milliard dollar. Med stramme helsebudsjetter kan man fantasere hva en slik sum kunne anvendes til ellers i helsevesenet og hvilken betydning det ville ha for befolkningens livskvalitet.
Gruppe IV omfatter sykdommer og manifestasjoner hvor grunnsykdommen er av ikke-revmatisk natur. En metastase fra prostatacancer lokalisert leddnært ville for eksempel kunne gi reaktiv synovitt.

Den inndelingen som er angitt $i$ dette kapitelet er det dessverre ingen bred enighet om. Hensikten med å presentere nettopp denne inndelingen er kun å gi leseren en rask oversikt over de revmatiske sykdommer. 